\title{
STUDI MUTU KAYU JATI DI HUTAN RAKYAT GUNUNGKIDUL. V. SIFAT KIMIA KAYU
}

\section{GANIS LUKMANDARU*, ARSYI RAHMAN MOHAMMAD, PITO WARGONO, \& VENDY EKO PRASETYO}

\author{
Departemen Teknologi Hasil Hutan, Fakultas Kehutanan, Universitas Gadjah Mada, \\ Jl. Agro No. 1, Bulaksumur, Sleman, 55281 \\ *Email: ganisarema@lycos.com
}

\begin{abstract}
This study aimed to explore the chemical properties of teak wood grown in community forests from Gunungkidul Regency. Trees (dbh 28-37 cm) were selected from three different sites i.e. Nglipar, Panggang, and Playen. Three trees were cut from each site and disks were taken from the base of the trees. The disk in radial cross section was divided into 3 parts: sapwood, outer heartwood, and inner heartwood. Chemical properties tested were holocellulose, $\alpha$-cellulose, hemicellulose, lignin, ethanol-toluene extractives, hot-water soluble extractives, solubility in $\mathrm{NaOH} 1 \%$, and ash contents. Mature teakwoods from Randublatung (Perhutani plantation) were used for comparison purpose. The values range of chemical composition in the cell wall components of the Gunungkidul teak wood were holocellulose content 75.76-79.74\%, , $\alpha$-cellulose content 46.72-50.90\%, hemicellulose content 27.41-30.14\%, lignin content $29.22-32.80 \%$, and solubility in NaOH $1 \%$ $16.43-17.35 \%$. Further, the ethanol-toluene extractive, hot-water soluble, and ash content values ranged from 5.04 to $10.77 \%, 2.74-7.85 \%$, and $0.60-1.66 \%$, consecutively. Interaction between two factors affects significantly to holocellulose, á-cellulose, hemicellulose, and ethanol-toluene extractive contents. The growth-site significantly influence on the ash contents as radial factor has significantly affect on the levels of hot water soluble extractives and ash content. The amounts of ethanol-toluene extractive and ash contents of Gunungkidul teak wood showed the lower values than those of teak from Randublatung. The values of other parameters were remain in the range of value of teak from Randublatung.
\end{abstract}

Keywords: Tectona grandis, chemical properties, community forest, radial direction, Gunungkidul.

\section{INTISARI}

Penelitian ini bertujuan untuk mengeksplorasi sifat kimia kayu jati dari hutan rakyat Kabupaten Gunungkidul. Pohon (dbh 28-37 cm) diambil dari tempat tumbuh berbeda yaitu Nglipar, Panggang, dan Playen. Setiap tempat diambil 3 pohon sebagai ulangan dan sampel yang digunakan adalah disk yang diambil dari bagian pangkal. Penampang radial disk dibagi menjadi 3 bagian, yaitu gubal, teras luar, dan teras dalam. Sifat kimia yang diuji adalah kadar holoselulosa, a-selulosa, hemiselulosa, lignin, ekstraktif etanol-toluena, kelarutan dalam air panas, kelarutan dalam $\mathrm{NaOH} \mathrm{1 \% ,} \mathrm{dan} \mathrm{abu.} \mathrm{Sebagai} \mathrm{pembanding,} \mathrm{digunakan} \mathrm{kayu} \mathrm{jati}$ dewasa dari tegakan Randublatung (Perhutani). Kisaran nilai kimia dari komponen dinding sel kayu jati Gunungkidul adalah kadar holoselulosa 75,76-79,74\%, $\alpha$-selulosa 46,72-50,90\%, hemiselulosa 27,41-30,14\%, lignin 29,22-32,80\%, dan kelarutan dalam NaOH 1\% sebesar 16,43-17,35\%. Selanjutnya, kadar ekstraktif etanol-toluena, kelarutan dalam air panas, dan abu adalah 5,04-10,77\%, 2,74-7,85\%, dan 0,60-1,66\%, secara berurutan. Interaksi antara kedua faktor berpengaruh nyata pada kadar holoselulosa, $\alpha$-selulosa, hemiselulosa, dan ekstraktif etanol-toluena. Faktor tempat tumbuh berpengaruh nyata pada kadar abu sedangkan faktor radial berpengaruh nyata pada kadar kelarutan dalam air panas dan abu. Kayu jati dari Gunungkidul memberikan nilai rerata kadar ekstraktif etanol-toluena dan abu yang lebih rendah sedangkan nilai di parameter lainnya masih dalam kisaran nilai kayu jati dari Randublatung.

Kata kunci: Tectona grandis, sifat kimia, hutan rakyat, arah radial, Gunungkidul. 


\section{PENDAHULUAN}

Salah satu jenis kayu yang sangat diminati untuk kebutuhan masyarakat adalah kayu jati (Tectona grandis L.f.). Kayu jati telah ditanam beberapa abad yang lalu dan menjadi komoditas bagi masyarakat hingga saat ini. Karena sifatnya yang baik, kayu jati merupakan jenis kayu yang banyak dipakai untuk berbagai keperluan, seperti bahan konstruksi, dek kapal, dan lantai (Martawijaya et al.,1981). Jati tumbuh baik pada tanah sarang terutama tanah yang mengandung kapur seperti daerah Gunungkidul, Yogyakarta, yang banyak ditemukan di hutan rakyat.

Kayu jati dari hutan rakyat tidak mendapatkan perlakuan silvikultur seperti kayu dari hutan tanaman, sehingga sifat kayu umumnya kurang baik dibandingkan kayu dari hutan tanaman (Abdurachman dan Hadjib, 2006). Selain itu, kayu jati di hutan rakyat pada umumnya dipanen pada umur yang relatif lebih muda. Hal ini diduga dapat mempengaruhi persen gubal dan persen teras yang dihasilkan. Pohon atau bagian pohon yang masih muda dan tumbuh dengan suburnya sering tidak mengandung kayu teras (Shmulsky dan Jones, 2011). Oleh karena itu, besar kemungkinan kayu-kayu dari hutan rakyat memiliki persen teras yang lebih rendah. Akibat dari lebih rendahnya persen teras tersebut dikhawatirkan kayu jati dari hutan rakyat memiliki kadar ekstraktif yang lebih rendah.

Berdasar catatan Dinas Kehutanan dan Perkebunan Kab. Gunungkidul bahwa hutan rakyat di Gunungkidul luasnya mencapai 41.180,97 ha dan tersebar di 18 kecamatan (Badan Pusat Statistik Kab. Gunungkidul, 2013). Hutan rakyat tersebar di tiga zona, yaitu zona utara (Nglipar), zona tengah (Playen), zona selatan (Panggang), yang memiliki karakteristik yang berbeda, baik topografi, ketinggian dari permukaan laut, jenis tanah, curah hujan, maupun jenis sungainya. Dapat diduga bahwa variasi tempat tumbuh tersebut dapat mempengaruhi sifat-sifat kayu jati. Dalam beberapa penelitian, perbedaan asal tempat tumbuh mempengaruhi kadar silika dan kalsium pada kayu jati (Kajornsrichon dan Lauridsen, 1998), kadar lignin, dan polisakarida (Windeisen et al., 2003), serta kadar ekstraktif (Bhat et al., 2005; Lukmandaru, 2012). Proporsi komponen kimia penyusun kayu sangat bervariasi dari jenis kayu yang satu ke jenis yang lain dan dari pohon ke pohon pada masing-masing jenis kayu bahkan dari bagian-bagian suatu pohon, misalnya pada kedudukan radial kayu (Sjostrom, 1998). Adanya variasi pada kedudukan radial kayu disebabkan oleh perbedaan musim tumbuh saat kayu dibentuk serta adanya pengaruh kayu juvenil.

Pemanfaatan optimal kayu jati hutan rakyat perlu didukung dengan mengetahui sifat-sifat dasar kayu jati antara lain sifat kimia. Dalam banyak penggunaan kayu secara teknologi data kuantitatif tentang komposisi kimia spesies kayu sering sangat diinginkan atau bahkan diperlukan untuk sejumlah proses (Fengel dan Wegener, 1995). Sifat kimia penting untuk diketahui karena dapat menentukan proses awal hingga proses akhir dari sebuah pengerjaan kayu. Data sifat-sifat kayu jati hutan rakyat masih sangat terbatas dibandingkan dengan jati hutan tanaman atau Perum Perhutani. Selain itu, antara hutan rakyat dan Perum Perhutani memiliki perbedaan pada kondisi tempat tumbuh. Hutan rakyat lebih bervariasi tempat tumbuhnya karena model tanamannya adalah campuran antara tanaman berkayu dan semusim. Maka dari itu perlu adanya penelitian yang bertujuan mengeksplorasi sifat kimia kayu jati hutan rakyat pada tempat tumbuh yang berbeda serta membandingkannya dengan kayu jati konvensional. Penelitian ini merupakan lanjutan dari karakterisasi sifat fisik jati di Gunungkidul (Marsoem et al., 2014; Marsoem et al., 2015). 


\section{BAHAN DAN METODE}

\section{Penyiapan Bahan}

Penelitian ini menggunakan kayu yang berasal dari pohon pada 3 tempat hutan rakyat yang berbeda di Gunungkidul, Yogyakarta (Gambar 1) yaitu Desa Girisekar, Panggang (zona utara), Desa Dengok, Playen (zona tengah), dan Desa Kedungkeris, Nglipar (zona selatan). Karakteristik tempat tumbuh dan sampel pohon dari Gunungkidul secara detail telah disajikan di penelitian pendahuluan (Marsoem, 2013, Marsoem et al.,2014) sedangkan umur tidak diketahui karena tidak tercatat tahun tanamnya. Dari masing-masing zona, diambil tiga pohon sebagai ulangan sehingga keseluruhan ada 9 pohon ditebang (kisaran dbh 28-37 cm, jumlah lingkaran tahun 10-21, persen teras 33-74\%). Pohon sampel ditentukan berdasarkan kualitas terbaik, yaitu pohon yang memiliki cacat minimal. Dari masing-masing pohon diambil sampel pada bagian pangkal $(20 \mathrm{~cm}$ dari permukaan tanah) berbentuk disk dengan ketebalan 5 $\mathrm{cm}$. Setiap disk dibagi menjadi tiga bagian pada kedudukan radial, yaitu gubal $( \pm 0,5 \mathrm{~cm}$ dari kulit), teras terluar $( \pm 0,5 \mathrm{~cm}$ dari perbatasan gubal-teras), dan teras dalam $( \pm 1 \mathrm{~cm}$ dari hati/empulur). Dari setiap bagian, sampel uji kayu kemudian dibuat serbuk ukuran 40-60 mesh untuk penentuan sifat-sifat kimianya. Sebagai pembanding, ditebang 3 pohon dari Perhutani KPH Randublatung KU VI (kisaran dbh 54-67 cm dengan jumlah lingkaran tahun 67-70, dan persen teras 94-97\%). Pengambilan spesimen dilakukan di bagian pangkal sedangkan proses sampling dalam arah radial langkah kerjanya sama dengan yang berasal dari hutan rakyat.

\section{Penentuan Sifat Kimia}

Penentuan kadar ekstraktif dilakukan dengan mengekstrak serbuk kayu setara $2 \mathrm{~g}$ berat kering tanur dengan pelarut etanol-toluena $(2: 1, \mathrm{v} / \mathrm{v})$ dengan alat soxhlet selama 8 jam (ASTM D1 107 - 96, 2002), serta dengan air panas selama 3 jam (ASTM D 1110 $80,2002)$ secara terpisah. Serbuk bebas ekstraktif

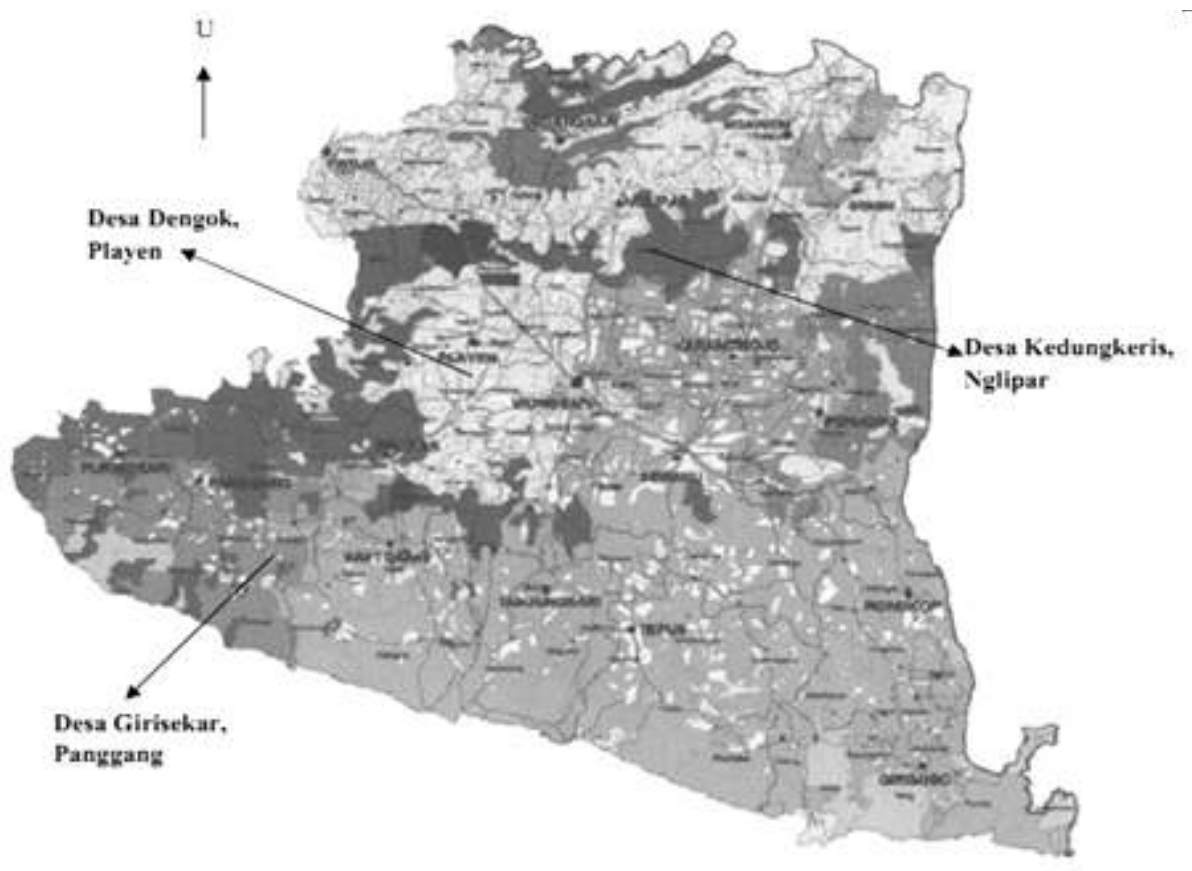

Gambar 1. Peta tempat pengambilan sampel pohon jati di tiga tempat hutan rakyat di Kabupaten Gunungkidul 
dari ekstraksi etanol-toluena selanjutnya diukur kadar holoselulosa dan $\alpha$-selulosa dengan metoda asam klorit modifikasi (Browning, 1967), dan lignin Klason melalui hidrolisis asam sulfat 72\% (TAPPI, T222 - os 78, 1992). Kadar hemiselulosa ditentukan melalui pengurangan kadar holoselulosa dengan kadar $\alpha$-selulosa. Parameter lainnya adalah kadar abu yang mengacu ASTM D 1102 - 84 (2002) sedangkan kelarutan dalam NaOH 1\% mengacu ASTM D 110984 (2002).

\section{Analisis Statistik}

Penelitian ini menggunakan rancangan acak lengkap yang disusun secara faktorial. Analisa keragaman atau variansi dwi-arah (two-way ANOVA) digunakan untuk mengetahui perbedaan di antara rerata parameter dalam 2 faktor (tempat tumbuh dan arah radial). Perbedaan dianggap nyata pada taraf uji 5\% sedangkan untuk uji lanjutan menggunakan uji Tukey HSD (honestly significant difference).
Perhitungan statistik dilakukan dengan menggunakan program SPSS versi 16.0.

\section{HASIL DAN PEMBAHASAN}

\section{Komponen Penyusun Dinding Sel}

Kisaran nilai holoselulosa, $\alpha$-selulosa, hemiselulosa, dan lignin kayu jati Gunungkidul dari semua pengukuran individu pohon secara berturutan adalah 75,76-79,74\%; 46,72-50,90\%; 27,41-30,14\%; dan 29,22-32,80\% (tidak semua data ditampilkan). Rerata berdasarkan tempat tumbuh telah diringkas di Tabel 1. Dari penelitian sebelumnya, nilai $\alpha$-selulosa dan lignin dari penelitian ini masih lebih tinggi dari nilai jati dari tegakan Perhutani (Syafi'i, 2000), sedangkan kadar hemiselulosanya masih dalam kisaran. Untuk kadar lignin, nilai yang diperoleh masih di bawah jati dari Brazil (Polato et al., 2005) atau Panama (Windeisen et al., 2003) tetapi dalam kisaran yang diperoleh Wangaard (1966).

Tabel 1. Sifat kimia kayu jati dari hutan rakyat Kabupaten Gunungkidul, tegakan Randublatung dan referensi

\begin{tabular}{|c|c|c|c|c|c|c|c|c|c|}
\hline \multirow{2}{*}{ Sifat kimia (\%) } & \multicolumn{3}{|c|}{ Gunungkidul } & \multirow[t]{2}{*}{ Randublatung } & \multicolumn{5}{|c|}{ Referensi } \\
\hline & Panggang & Playen & Nglipar & & Martawijaya $^{1}$ & Syafi' $^{2}$ & Polato $^{3}$ & Windeisen $^{4}$ & Wangaard $^{5}$ \\
\hline $\begin{array}{l}\text { Kadar ekstraktif } \\
\text { etanol-toluenab }\end{array}$ & $\begin{array}{c}7,40 \\
(2,99)\end{array}$ & $\begin{array}{c}6,17 \\
(0,93)\end{array}$ & $\begin{array}{c}7,33 \\
(1,20)\end{array}$ & $\begin{array}{c}8,48 \\
(3,88)\end{array}$ & 4,6 & $\begin{array}{l}3,81- \\
10,56\end{array}$ & $\begin{array}{l}7,2- \\
9,8\end{array}$ & & 11,3 \\
\hline $\begin{array}{l}\text { Kelarutan dalam } \\
\text { air panas }\end{array}$ & $\begin{array}{c}4,19 \\
(1,48)\end{array}$ & $\begin{array}{c}5,25 \\
(2,35)\end{array}$ & $\begin{array}{c}5,08 \\
(2,35)\end{array}$ & $\begin{array}{l}4,30 \\
(0,63)\end{array}$ & 11,1 & $\begin{array}{c}5,23- \\
7,16\end{array}$ & $\begin{array}{l}0,6- \\
2,5\end{array}$ & $1,8-5,2$ & - \\
\hline $\begin{array}{l}\text { Kelarutan dalam } \\
\mathrm{NaOH} 1 \% \mathrm{~b}\end{array}$ & $\begin{array}{l}16,96 \\
(0,62)\end{array}$ & $\begin{array}{l}17,42 \\
(1,04)\end{array}$ & $\begin{array}{l}17,95 \\
(0,63)\end{array}$ & $\begin{array}{l}16,94 \\
(0,46)\end{array}$ & 19,8 & $\begin{array}{l}14,10- \\
19,03\end{array}$ & - & & $15,4-25,0$ \\
\hline Holoselulosa $^{\mathrm{a}}$ & $\begin{array}{l}77,66 \\
(1,99)\end{array}$ & $\begin{array}{l}78,48 \\
(0,51)\end{array}$ & $\begin{array}{l}77,09 \\
(0,87)\end{array}$ & $\begin{array}{l}77,46 \\
(0,93)\end{array}$ & - & - & $\begin{array}{l}75,7- \\
78,8\end{array}$ & & $65,2-73,5$ \\
\hline$\alpha$-selulosa ${ }^{\mathrm{a}}$ & $\begin{array}{l}49,11 \\
(1,34)\end{array}$ & $\begin{array}{l}50,26 \\
(0,72)\end{array}$ & $\begin{array}{l}48,34 \\
(1,43)\end{array}$ & $\begin{array}{l}49,36 \\
(1,83)\end{array}$ & 47,5 & $\begin{array}{l}40,26- \\
45,25\end{array}$ & - & & $37,0-41,7$ \\
\hline Hemiselulosa $^{a}$ & $\begin{array}{l}28,55 \\
(1,36)\end{array}$ & $\begin{array}{l}28,22 \\
(0,79)\end{array}$ & $\begin{array}{l}28,75 \\
(1,32)\end{array}$ & $\begin{array}{l}28,09 \\
(0,90)\end{array}$ & - & $\begin{array}{l}24,30- \\
31,97\end{array}$ & - & & $28,2-31,8$ \\
\hline $\operatorname{Lignin}^{\mathrm{a}}$ & $\begin{array}{l}32,23 \\
(0,54)\end{array}$ & $\begin{array}{l}31,47 \\
(1,21)\end{array}$ & $\begin{array}{l}33,52 \\
(1,03)\end{array}$ & $\begin{array}{l}33,52 \\
(1,03)\end{array}$ & 29,9 & $\begin{array}{l}24,73- \\
29,94\end{array}$ & $37-41$ & $33,3-38,3$ & $32,2-36,3$ \\
\hline $\mathrm{Abu}^{\mathrm{b}}$ & $\begin{array}{c}0,81 \\
(0,19)\end{array}$ & $\begin{array}{c}1,52 \\
(0,17)\end{array}$ & $\begin{array}{c}1,07 \\
(0,14)\end{array}$ & $\begin{array}{c}1,59 \\
(0,32)\end{array}$ & 1,4 & $\begin{array}{c}0,57- \\
1,60\end{array}$ & $\begin{array}{l}0,7- \\
2,8\end{array}$ & & - \\
\hline
\end{tabular}

Keterangan : Rerata dari 3 pengukuran, tanda kurung menandakan standar deviasi.

$\mathrm{a}=$ persen dari berat serbuk bebas ekstraktif; $\mathrm{b}=$ persen dari serbuk awal setara kering tanur

Sumber: 1 Martawijaya et al., 1981; 2 Syafii, 2000; 3 Polato et al., 2005; 4 Windeisen et al., $2003 ; 5$ Wangaard, 1966.

Referensi 1, 2, 5 menggunakan pelarut etanol-benzena dan referensi 3 menggunakan pelarut etanol-sikloheksana dan ekstraksi berturutan dengan air panas. 
Penelitian kayu jati di tegakan Perhutani menunjukkan kecenderungan penurunan nilai kadar hemiselulosa serta kenaikan kadar selulosa dan lignin seiring umur (Syafi'i, 2000). Rerata nilai komponen dinding sel kayu jati Gunungkidul ini masih dalam kisaran sampel tegakan Randublatung. Apabila diasumsikan sampel di Gunungkidul merupakan kayu muda sedangkan sampel dari Randublatung merupakan kayu dewasa, maka faktor perbedaan tempat tumbuh diduga menjadi penyebab pola tersebut.

Hasil ANOVA (Tabel 2) menunjukkan adanya interaksi antara faktor tempat tumbuh dan posisi radial untuk kadar holoselulosa, $\alpha$-selulosa, dan hemiselulosa. Untuk kadar holoselulosa, didapatkan interaksi antara faktor tempat tumbuh dan radial berbeda nyata, namun pada kadar lignin tidak berbeda nyata pada semua faktor. Kandungan holoselulosa yang tinggi seharusnya menyebabkan kandungan lignin menjadi rendah. Kandungan lignin yang cenderung seragam pada semua faktor tidak diharapkan terjadi, hal ini diduga tidak sempurna dalam melarutkan lignin sehingga perlu dikoreksi dari kadar lignin terlarut asamnya yang sayangnya tidak dilakukan dalam penelitian ini. Adanya tumpang tindih antara kadar holoselulosa dan kadar lignin menyebabkan ketidaktentuan dalam penentuan kadar lignin (Fengel dan Wegener, 1995).
Secara detail, kadar holoselulosa tertinggi terdapat di bagian gubal kayu jati dari Panggang (79,74\%), sedangkan nilai tertinggi kadar $\alpha$-selulosa didapatkan di teras luar dari Playen (50,90\%), dan nilai kadar hemiselulosa tertinggi didapatkan di teras dalam dari Panggang (27,41\%). Pada kadar holoselulosa (Gambar 2), dapat dilihat kayu jati asal Nglipar dan Playen memiliki kecenderungan bagian gubal lebih rendah daripada bagian teras luar, namun terjadi perbedaan yang nyata pada kayu jati asal Panggang yang memiliki nilai kadar holoselulosa bagian gubal lebih besar daripada bagian teras luar. Penelitian pendahuluan (Marsoem, 2013) menunjukkan curah hujan di daerah Nglipar terendah sedangkan Panggang yang tertinggi dalam kurun 2009-2012. Kecenderungan tersebut sesuai di penelitian kayu jati dari Brasil (Polato et al., 2005) yang berasal dari daerah kering dan daerah basah. Berdasar faktor radialnya, rerata kadar holoselulosa dan hemiselulosa bagian gubal cenderung lebih besar daripada bagian yang lain. Hal ini berbeda dengan kadar $\alpha$-selulosa yang lebih besar di bagian teras luar daripada bagian yang lain. Meski belum pasti, diduga sintesa gula berberat molekul lebih besar seperti selulosa menjadi lebih intensif seiring waktu dimana gubal yang kemudian berubah menjadi teras. Kecenderungan yang sama juga didapatkan pada kayu Cedrus libani (Usta dan Kara, 1997).

Tabel 2. Analisis varians (keragaman)kadar komponen penyusun dinding sel kayu jati dari hutan rakyat Gunungkidul

\begin{tabular}{lccccc}
\hline \multirow{2}{*}{ Sumber Keragaman } & Derajat & \multicolumn{4}{c}{ Kuadrat Tengah } \\
\cline { 3 - 6 } & Bebas & Holoselulosa & $\alpha$ selulosa & Hemiselulosa & Lignin \\
\hline Radial & 2 & 1,29 & 0,68 & $3,84^{*}$ & 0,82 \\
Tempat tumbuh & 2 & $4,40^{*}$ & $8,40^{*}$ & 0,64 & 3,54 \\
Radial xtempat tumbuh & 4 & $6,86^{* *}$ & $6,24^{*}$ & $4,47^{* *}$ & 5,78 \\
Galat & 18 & 0,84 & 1,93 & 0,94 & 3,05 \\
\hline \multicolumn{2}{l}{ Total } & 26 & \multicolumn{4}{c}{} \\
\hline Keterangan :** = beda sangat nyata pada taraf uji 1\% & $*$ = beda nyata pada taraf uji 5\%
\end{tabular}


Tidak ditemukan adanya pengaruh yang nyata, baik pada interaksi antara kedua faktor maupun pada masing-masing faktor pada kadar lignin (Tabel 2). Di kayu keras banyak diamati tidak adanya perbedaan kadar lignin antara kayu juvenil dengan kayu dewasa (Pereira et al., 2003). Untuk faktor tempat, berbeda dengan penelitian sebelumnya pada kayu jati Panama dimana terdapat perbedaan kadar lignin pada daerah curah hujan tinggi dan rendah (Windeisen et al., 2003). Hal ini mengindikasikan kadar lignin pada

\section{QGubal DTerasluar DTeras Dalam}

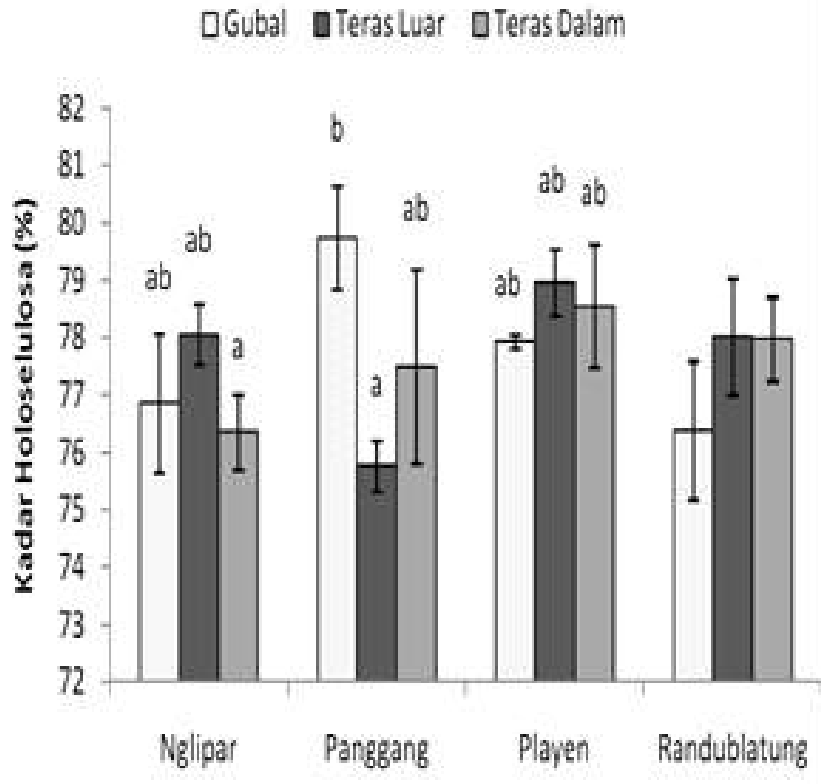

penelitian ini lebih dipengaruhi faktor selain arah radial dan tempat tumbuh.

Komposisi kimia untuk bahan baku kayu solid mempunyai arti penting dalam kaitannya dengan mekanika kayu dimana secara umum selulosa membentuk kerangka dinding sel, hemiselulosa berperan membentuk matriks bahan sedangkan lignin memberi kekakuan kayu (Kollman dan Côté, 1968). Curling et al. (2002) mendemonstrasikan sensitivitas kekuatan kayu yang dipengaruhi oleh gula-gula dari hemiselulosa. Pengaruh lainnya
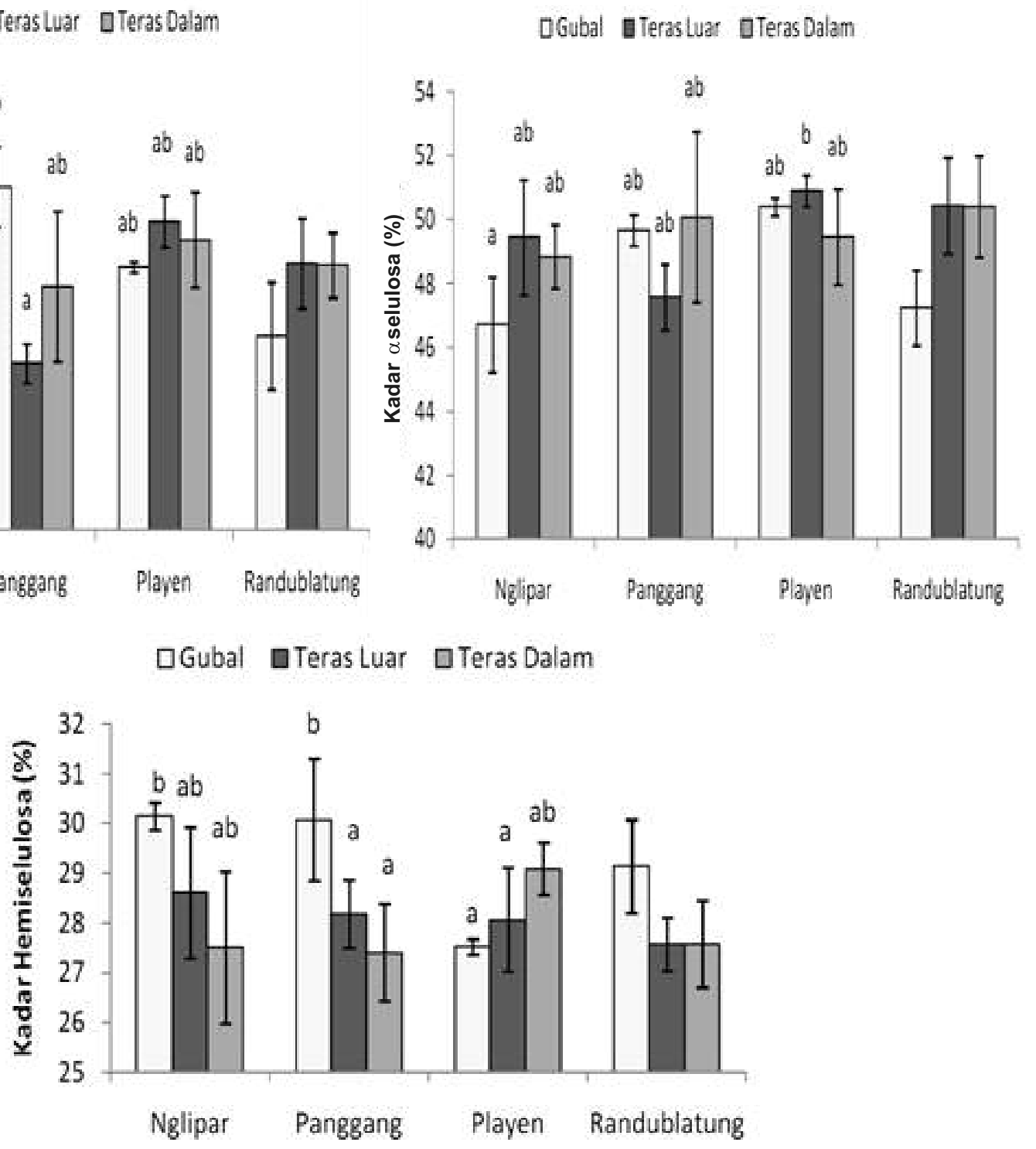

Gambar 2. Kadar holoselulosa, a-selulosa, dan hemiselulosa kayu jati dari hutan rakyat Gunungkidul dan Randublatung dalam perbedaan tempat tumbuh dan arah radial. Huruf yang sama menunjukkan tidak beda nyata pada taraf uji 5\% dalam uji Tukey HSD. 
adalah pada perubahan dimensi yang dalam taraf tertentu dipengaruhi oleh lignin (Barcenas-Pazos et al.,2000). Dalam penelitian ini, kadar lignin relatif homogen di tiga tempat tumbuh maupun di arah radial tersebut tetapi tidak demikian halnya dengan fraksi polisakarida. Penelitian di sampel yang sama terhadap parameter penyusutan kayu menunjukkan adanya pengaruh faktor tempat tumbuh maupun arah radialnya (Marsoem et al., 2014) demikian juga terhadap sifat mekanika kayunya (Marsoem et al., 2015). Perbedaan kecenderungan tersebut mengindikasikan interaksi kompleks dalam antara komponen dinding sel dalam pengaruhnya terhadap sifat fisik maupun mekanika di kayu jati.

\section{Kadar Ekstraktif}

Nilai kadar ekstraktif etanol-toluena (KET), kelarutan dalam air panas (KAP), dan kelarutan dalam $\mathrm{NaOH}$ 1\% kayu jati Gunungkidul dari semua pengukuran berkisar antara 5,04-10,77\%; 2,747,85\%; dan 16,43-17,35\%, secara berturutan. Rerata nilai berdasarkan tempat tumbuh dideskripsikan di Tabel 1. Apabila dibandingkan dengan sampel dari Randublatung, maka rerata KET dari sampel Gunungkidul sedikit lebih rendah yang diduga karena faktor umur (Haupt et al., 2003). Di lain pihak, selisih nilai rerata KAP atau $\mathrm{NaOH} 1 \%$ tidaklah berbeda jauh bila dibandingkan sampel dari Randublatung. Kisaran hasil KET dari penelitian ini nilainya sesuai dengan penelitian sebelumnya pada kayu jati Indonesia sebesar 6-8\% (Da Costa et al., 1958) dan 3-11\% (Syafi'i, 2000), namun relatif lebih rendah dari jati India yaitu 12-16\% (Bhat et al., 2005). Nilai KAP dan larut $\mathrm{NaOH} 1 \%$ jati Gunungkidul kecenderungannya cukup bervariasi bila dibandingkan dengan jati Indonesia yang dipublikasikan oleh Lukmandaru (2011), Syafi'i (2000) atau Martawijaya et al. (1981) yang diduga karena variasi umur sampel dan tempat tumbuhnya.

Hasil ANOVA (Tabel 3) menunjukkan ada interaksi nyata antara faktor tempat tumbuh dan arah radial di parameter KET sedangkan KAP dipengaruhi nyata oleh faktor tunggalnya. Tidak ada pengaruh nyata kedua faktor di atas terhadap kelarutan dalam $\mathrm{NaOH}$ 1\%. KET mengukur banyaknya zat lilin, lemak, resin, minyak, tanin serta senyawa lain yang tidak larut dalam eter (ASTM, 2002). Penelitian sebelumnya menunjukkan kayu jati yang ditanam di daerah basah memiliki kadar ekstraktif yang lebih rendah (Bhat et al., 2005; Windeisen et al., 2003). Hasil uji lanjut Tukey menunjukkan KET tertinggi terdapat pada bagian teras luar kayu jati dari Panggang (10,77\%) dan dari Nglipar (8,69\%) yang berbeda nyata dibandingkan dengan bagian-bagian yang lain. Data curah hujan menunjukkan ada perbedaan curah hujan meski tidak begitu ekstrim di antara ketiga tempat tersebut (Marsoem, 2013) sehingga diduga penyebabnya lebih ke faktor edafis. Berdasar tempat tumbuhnya,

Tabel 3. Analisis varians (keragaman) kadar ekstraktif dan abu kayu jati dari hutan rakyat Gunungkidul

\begin{tabular}{|c|c|c|c|c|c|}
\hline \multirow[b]{2}{*}{ Sumber Keragaman } & \multirow{2}{*}{$\begin{array}{l}\text { Derajat } \\
\text { Bebas }\end{array}$} & \multicolumn{4}{|c|}{ Kuadrat Tengah } \\
\hline & & $\begin{array}{c}\text { Kadar ekstraktif } \\
\text { etanol-toluena }\end{array}$ & $\begin{array}{l}\text { Kelarutan dalam } \\
\text { air panas }\end{array}$ & $\begin{array}{c}\text { Kelarutan dalam } \\
\text { NaOH } 1 \%\end{array}$ & $\mathrm{Abu}$ \\
\hline Radial & 2 & $26,37 * *$ & $38,11 * *$ & 1,59 & $0,26^{*}$ \\
\hline Tempat tumbuh & 2 & $4,30 *$ & 2,87 & 2,77 & $1,17^{* *}$ \\
\hline Radial x Tempat tumbuh & 4 & $3,77^{*}$ & 0,91 & 1,79 & $0,01>$ \\
\hline Galat & 18 & 1,18 & 1,43 & 2,06 & 0,07 \\
\hline Total & 26 & & & & \\
\hline
\end{tabular}

Keterangan $: * *=$ beda sangat nyata pada taraf uji $1 \% \quad *=$ beda nyata pada taraf uji $5 \%$ 
perbedaan paling mencolok dari ketiga tempat tersebut adalah di daerah Panggang yang merupakan daerah berbatu dengan lapisan top soil yang tipis bila dibandingkan kedua tempat tumbuh lainnya.

Kecenderungan KET pada hutan rakyat tertinggi diperoleh di bagian teras luar. Teras luar di kayu jati memiliki kadar ekstraktif yang lebih tinggi dibandingkan dengan bagian gubal, maupun bagian teras dalam sesuai dengan hasil studi sebelumnya (Narayanamurti et al., 1962; Rudman et al., 1966). Diasumsikan KET nilainya tidak jauh berbeda dengan kadar etanol-benzena, maka KAT di bagian teras luar jati Gunungkidul ini masih dalam kisaran nilai penelitian dari tegakan Perhutani untuk umur yang bersesuaian yaitu sebesar 4-11\% (Lukmandaru, 2009; 2011; 2012).

Beberapa ekstraktif yang larut air juga terlarut dalam ekstrak etanol-toluena, misalnya tanin (Fengel dan Wegener, 1995), sehingga ada tumpang tindih dalam jumlah antara kedua golongan pelarut tersebut karena proses ekstraksi tidak dilakukan secara berurutan. Untuk jati yang berasal dari Brazil, ekstraksi berurutan menunjukkan nilai kadar ekstraktif etanol-sikloheksana lebih tinggi dibandingkan KAP (Polato et al., 2005). Pada penelitian ini, nilai KAP juga lebih kecil daripada KET (Tabel 1) meski dalam ekstraksi terpisah. Berdasar arah radialnya (Gambar 3), KAP tertinggi adalah pada bagian gubal kayu (7,08\%) dan terendah pada bagian teras dalam (3,02\%). Setelah dilakukan uji lanjut, bagian gubal berbeda nyata dengan bagian teras luar dan teras dalam. Pola yang sama juga diamati di jati Randublatung meski tidak dilakukan pengujian statistik. Kecenderungan KAP yang lebih tinggi di kayu gubal dibanding teras diduga karena fungsi fisiologisnya. Ekstraktif yang terlarut air berupa komponen utama pertumbuhan atau esktraktif primer yang terdiri atas karbohidrat, protein, dan garam-garam anorganik banyak terdapat di bagian gubal (Fengel dan Wegener, 1995).

Faktor tempat tumbuh tidak berpengaruh nyata pada KAP tetapi nilai KET dipengaruhi interaksi kedua faktor. Beberapa sampel Gunungkidul dengan nilai KAP dan KET yang masih dalam kisaran jati Randublatung perlu dicatat sebagai bahan evaluasi sifat perekatan maupun keawetan alami dari jati
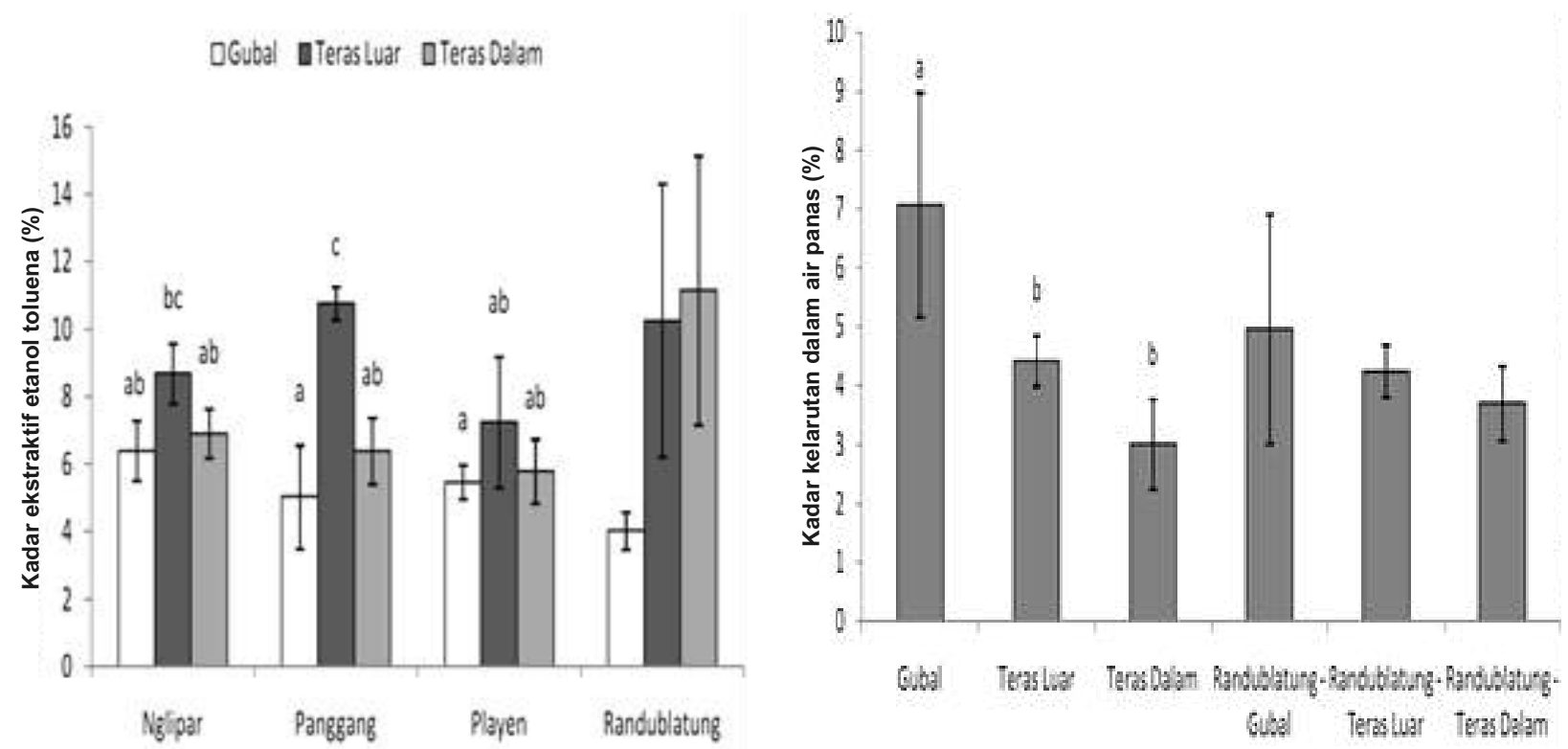

Gambar 3. Kadar ekstraktif etanol-toluena dan larut air panas kayu jati dari hutan rakyat Gunungkidul dan Randublatung dalam perbedaan tempat tumbuh dan arah radial. Huruf yang sama menunjukkan tidak beda nyata pada taraf uji $5 \%$ dalam uji Tukey HSD. 
Gunungkidul dalam penelitian lanjutan. Studi oleh Kanazawa et al. (1978) mengamati bahwa ekstrak air panas dari jati bersifat menghambat perekatan. Penelitian oleh Sakuno dan Moredo (1998) mendemonstrasikan korelasi negatif antara kadar ekstraktif larut etanol-benzena dengan kualitas perekatan, yang selanjutnya disebutkan ekstraksi pendahuluan dengan heksana akan memperbaiki sifat rekat pada sampel jati. Dari kerangka pandang tersebut maka KAP dan KET yang rendah akan lebih menguntungkan. Di lain pihak, nilai KET yang tinggi akan menguntungkan pada aspek keawetan alami, ketahanan cuaca, serta warna kayu dimana sifat-sifat tersebut yang memang diharapkan dari jati sebagai fancy wood.

\section{Kadar Abu}

Abu merupakan garam yang diendapkan dalam dinding sel dan lumen. Endapan yang khas adalah berbagai garam-garam logam, seperti karbonat, silikat, oksalat, dan fosfat (Sjostrom, 1998). Nilai kadar abu dari semua pengukuran sampel jati Gunungkidul adalah 0,60-1,66\%. Rerata nilai

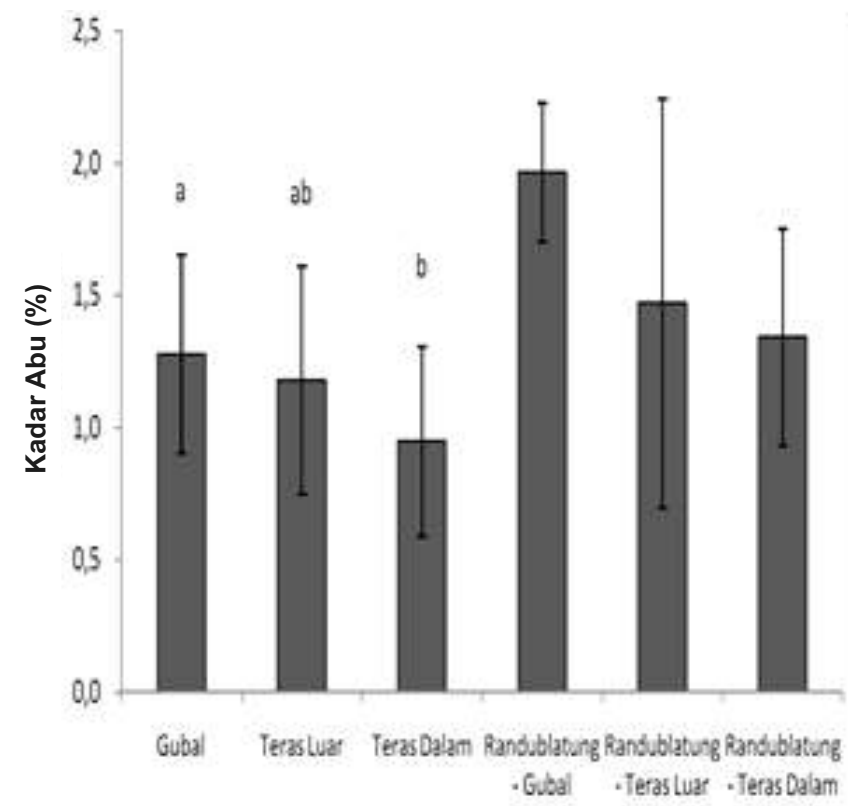

berdasarkan tempat tumbuh disarikan di Tabel 1 . Dapat dilihat bahwa bila dibandingkan dengan jati Randublatung, nilai rerata sampel di Gunungkidul menunjukkan nilai kadar abu yang lebih rendah.

Variasi dari kadar abu dipengaruhi oleh kondisi lingkungan (letak, iklim) dan pada lokasi di dalam pohon (Fengel dan Wegener, 1995). Hasil ANOVA menunjukkan pengaruh nyata arah radial maupun tempat tumbuh meski tidak berinteraksi (Tabel 3). Hasil uji lanjut Tukey disajikan dalam Gambar 4. Pengukuran kadar abu dalam posisi radial menunjukkan nilainya cenderung menurun dan berbeda nyata dari gubal $(1,28 \%)$ sampai ke teras dalam $(0,95 \%)$, seperti halnya pola di jati Randublatung. Kecenderungan yang serupa di nilai KAP ini juga berkaitan dengan fungsi fisiologis kayu gubal sebagai penghantar unsur hara/nutrisi dari akar ke ke daun (Shmulsky dan Jones, 2011).

Berdasar tempat tumbuhnya (Gambar 4), hasil pengukuran menunjukkan kayu jati yang berasal dari daerah Panggang $(0,81 \%)$ memiliki nilai kadar abu yang paling rendah sedangkan Playen yang tertinggi

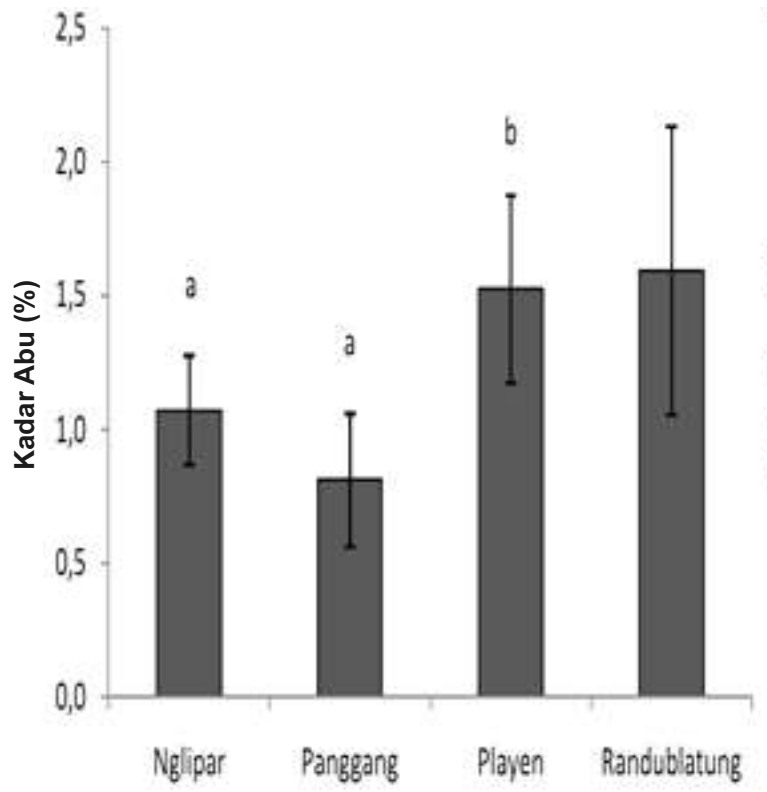

Gambar 4. Kadar abu kayu jati dari hutan rakyat Gunungkidul dan Randublatung dalam perbedaan tempat tumbuh dan arah radial. Huruf yang sama menunjukkan tidak beda nyata pada taraf uji5 \% dalam uji Tukey HSD. 
(1,53\%). Hal ini diduga karena pohon tumbuh di tanah berbatu dan lapisan top soil tipis sehingga unsur hara relatif tidak banyak diserap khususnya di daerah Panggang. Perlu dicatat bahwa sampel dari Playen nilai reratanya mendekati jati di Randublatung (Tabel 1).

Silika merupakan penyusun unsur abu yang umumnya ditemukan dalam jumlah lebih bervariasi dan banyak di kayu daun lebar tropis (Shmulsky dan Jones, 2011). Selanjutnya disebutkan kayu dengan kandungan silika lebih tinggi dari nilai kira-kira 0,3\% akan menyebabkan alat-alat pemotong menjadi lebih mudah tumpul. Meski belum diketahui secara pasti berapa persen silika dalam abu jati, dari sudut pandang kayu gergajian secara umum rerata nilai kadar abu Gunungkidul yang lebih rendah dari Randublatung tentunya merupakan keuntungan. Demikian juga halnya untuk produk perekatan karena unsur-unsur abu seperti kalsium, magnesium, dan potasium dalam bentuk garam dan gula asam merupakan penghambat utama dalam pengerasan perekat urea resin di kayu jati (Kanazawa et al., 1978)

\section{KESIMPULAN}

Nilai kadar holoselulosa, $\alpha$-selulosa, hemiselulosa, dan ekstraktif larut etanol-toluena jati hutan rakyat Gunungkidul dipengaruhi secara nyata oleh interaksi antara faktor tempat tumbuh dan posisi radial. Nilai kadar abu dipengaruhi secara nyata oleh faktor tempat tumbuh serta kadar ekstraktif larut air panas dan abu dipengaruhi secara nyata oleh faktor radial. Tidak ada pengaruh nyata faktor tempat tumbuh dan faktor radial terhadap kadar lignin dan kelarutan dalam $\mathrm{NaOH}$ 1\%. Dibandingkan dengan jati dari Randublatung, rerata nilai kadar ekstraktif etanol-toluena dan abu kayu jati dari Gunungkidul ini nilainya lebih rendah, sedangkan di sifat kimia lainnya nilainya masih dalam kisaran.

\section{UCAPAN TERIMA KASIH}

Penelitian ini dibiayai melalui skema Hibah Kompetitif Penelitian Sesuai Prioritas Nasional Nomor: 177/SP2H/PP/DP2M/V/2009 - DIKTI. Penulis mengucapkan terima kasih kepada Untoro Tri Kurniawan (Perum Perhutani) yang telah menyediakan sampel kayu jati dari KPH Randublatung.

\section{DAFTAR PUSTAKA}

Abdurachman \& Hadjib N. 2006. Pemanfaatan kayu hutan rakyat untuk komponen bangunan. Prosiding Seminar Hasil Litbang Hasil Hutan. 150-148.

American Society for Testing and Materials. 2002. Annual Book of ASTM Standards. Section Four Construction Volume 04.10 Wood. West Conshohocken, PA.

Badan Pusat Statisik Kabupaten Gunungkidul. 2013. Gunungkidul dalam Angka 2012. Badan Pusat Statisik Kabupaten Gunungkidul. 225.

Bárcenas-Pazos G, Velázquez-Morales P, \& Dávalos-Sotelo R. 2000. Effect of lignin content on shrinkage of four Mexican woods. Holzforschung 54, 541-543.

Bhat KM, Thulasidas PK, Florence EJM, \& Jayaraman K. 2005. Wood durability of home-garden teak against brown-rot and white-rot fungi. Trees 19, 654-660.

Browning BL. 1967. Methods of Wood Cemistry Vol.II. Interscience Publishers, A Division of John Wiley and Sons, Inc. New York.

Curling SF, Clausen CA, \& Winandy JE. 2002. Relationships between mechanical properties, weight loss, and chemical composition of wood during incipient brown-rot decay. Forest Product Journal 52, 34-39.

Da Costa EWB, Rudman P, \& Gay FJ.1958. Investigations on the durability of Tectona grandis. Empirical Forestry Review 37, 291-298.

Fengel D \& Wegener G. 1995. Kayu : Kimia, Ultrastruktur, Reaksi-reaksi. Gadjah Mada University Press (terjemahan). Yogyakarta. 
Haupt M, Leithoff H, Meier D, Puls J, Richter HG, \& Faix O. 2003. Heartwood extractives and natural durability of plantation-grown teakwood (Tectona grandis L.f) - A case study. Holz als Roh- und Werkstoff 61, 473-474.

Kajornsrichon S \& Lauridsen EB. 1998. Heartwood,calcium and silica content in five provenances of teak (Tectona grandis L.f.). Silvae Genetica 48, 1-3.

Kanazawa H, Nakagami T, Nobashi K, \& Yokota T. 1978. Studies on the gluing of the wood. Articles XI. The effects of teak wood extractives on the curing reaction and the hydrolysis rate of the resin urea adhesive. Mokuzai gakkaishi 24, 55-59.

Kollman FFP \& Côté Jr WA. 1968. Principles of Wood Science and Technology. Solid Wood 1. Springer, Berlin. 55-56.

Lukmandaru G. 2009. Pengukuran kadar ekstraktif dan sifat warna pada kayu teras jati doreng (Tectona grandis). Jurnal Ilmu Kehutanan 3(2), 67-73.

Lukmandaru G. 2011. Komponen kimia kayu jati dengan pertumbuhan eksentris. Jurnal Ilmu Kehutanan 5(1), 21-29.

Lukmandaru G. 2012. Chemotaxonomic study in the heartwood in the heartwood of Javanese teak analysis of quinones and other related components. Wood Research Journal 3(1), 30-35.

Martawijaya A, Kartasudjana I, Kadir K, \& Amongprawira S. 1981. Atlas Kayu Indonesia Jilid I. Balai Penelitian Hasil Hutan. Badan Litbang Kehutanan. Bogor. 42-47.

Marsoem SN. 2013. Studi mutu kayu jati di hutan rakyat Gunungkidul. I. Pengukuran laju pertumbuhan. Jurnal Ilmu Kehutanan 7, 108-122.

Marsoem SN, Prasetyo VE, Sulistyo J, Sudaryono, \& Lukmandaru G. 2014. Studi mutu kayu jati di hutan rakyat Gunungkidul. III. Sifat fisika kayu. Jurnal Ilmu Kehutanan 8, 76-88.

Marsoem SN, Prasetyo VE, Sulistyo J, Sudaryono, \& Lukmandaru G. 2015. Studi mutu kayu jati di hutan rakyat Gunungkidul. IV. Sifat mekanika kayu. Jurnal Ilmu Kehutanan 9, 117-127.

Narayanamurti D, George J, Pant HC, \& Singh J. 1962. Extractives in teak. Silvae Genetica 11(3), 57-63.

Pereira H, Graca J, \& Rodrigues JC. 2003. Wood chemistry in relation to quality. Dalam: Wood Quality and Its Biological Basic. Barnett RJ \& Jeronimidis G. (Ed.). Blackwell Publishing Ltd. USA.
Polato R, Laming PB, \& Sierra-Alvarez R. 2005. Assessment of some wood characteristic of teak of Brazilian origin. Quality Timber Product of Teak from Sustainable Forest Management. 257 265.

Rudman P, Da Costa EWB, \& Gay FJ. 1966. Wood quality in plus trees of teak (Tectona grandis L. f.). Sylvae Genetica 16, 102-105.

Sakuno T \& Moredo C. 1998. Bonding properties of some tropical woods after solvent extraction. Proceeding of the Second International Wood Science Seminar. Serpong, Indonesia. 183-189.

Shmulsky R \& Jones PD. 2011. Forest Products and Wood Science: An Introduction, Sixth Edition. John Wiley \& Sons, Inc.

Sjostrom E. 1998. Kimia Kayu: Dasar-Dasar Penggunaan. Gadjah Mada University Press (terjemahan). Yogyakarta.

Syafi'i W. 2000. The basic properties of Indonesia teakwood at various age classes. Dalam: Proceedings of the 3rd International Wood Science Symposium JSPS-LIPI Core University Program in the field of Wood Science. 300-304.

Technical Association for the Pulp and Paper Industries. 1992. TAPPI Test Method T 222 os-74. TAPPI Press. Atlanta.

Usta M \& Kara Z. 1997. The chemical composition of wood and bark of Cedrus libani A. Rich. Holz als Roh-und Werkstoff 55, 268.

Wangaard FF. 1966. Resistance of wood to chemical degradation. Forest Product Journal 16(2), 53-64.

Windeisen E, Klassen A, \&Wegener G. 2003. On the chemical characterisation of plantation teakwood from Panama. Holz als Roh- und Werkstoff 61,416-418. 